\title{
Study on College Students' Archives Management
}

\author{
Haiqing Pang \\ Youth League Committee, Dezhou University \\ Dezhou 253023, China \\ E-mail: panghaiqing3898@126.com
}

\begin{abstract}
At present, many problems exist in the work of college students' archives management. For example, relative systems and mechanisms are not perfect, the collection and treatment of students' archives are not standard, and students' consciousness of archives is too weak, which all limit the development of the archives works. In the new situation that the enrollment scale of colleges is continually expanding and the employment channel is not certain, to enhance the students' archives management level and work efficiency, it is very important to perfect the archives management system, standardize various management systems, strengthen the group training of students' archives management, enrich the content of the students' archives, and actively push the networking of students' archives management.
\end{abstract}

Keywords: Archives management system, Archives transmitting, Electronic archives

As the personal records, college students' archives "is the part of the national personal records, and it is the real historical records of college students' learning and various social practices, and it is the important reference for college students' employment, selection, appointment, and assessment in the future, and it is the base of each person's personnel archives", and it could mainly reflect students' experiences in the colleges, and it is the important life experience from the college to the society for each person. It includes students' status, achievements, military assessment, evaluations, punishing and withdrawing decisions, comprehensive evaluation form, the materials about the admission into the party and the league, the political records examination materials, performance records, graduated psychical checking, diploma counterfoil, and graduates registration form. As the important measure of the college student management and the graduate recommendation to the talent market, to do college students' archives work well is very important to enhance the student management level and the work efficiency in the new situation that the enrollment scale of colleges is continually expanding and the employment channel is not certain. Because of many causes, the work of college students' archives has not be emphasized enough, and the collection of archives materials is not complete, and college students' performance could not be reflected exactly and comprehensively.

\section{Actuality of the college students' archives management}

\subsection{The management system and mechanism of students' archives are not perfect}

As one branch of the college archives, the student archives has not one management departments, and the archives, the organization or personal department, the student work department, or various colleges (departments) respectively collect and manage various parts of students' archives, because of numerous content, quantity and quick flow of filling, the collection and treatment is a subtle and complex work, which needs more professional personnel, but most colleges lack in professional personnel, and necessary supervision and operations, and scientific management system, so the collection and treatment of students' archives has not been standardized, and many errors such as faking, simple content, uncompleted procedures, nonstandard filling, lagged time and difficult inquiry, all will occur in the file transfer, and seriously influence college students' employment market.

\subsection{The collection and treatment of students' archives are not standard}

Because the college students' archives management has not definite filing range and requirement about students' archives, various kinds of materials which could fully reflect students' comprehensive quality could not be filled, and the content is too simple and deficient, and the words materials have not uniform sheets and writings, even have wrongly written or mispronounced characters, and the director teachers' identifications all are singular, and students' comprehensive quality could not be reflected scientifically. Not only employment unit could not know students comprehensively, but also college teachers could not know students and teach students in accordance of their aptitudes. 


\subsection{The collection time of students' archives is not reasonable}

The collection and treatment of most college students' archives happen at the eve of the graduate, and because of urgent time and heavy task, many records reflecting students' daily learning, practice, and activity participation could be collected, especially those materials reflecting students' practice ability and individual characters, such as honor certificates, level examination certificates, could not be collected in time, even some archives materials are often lost, and the thesis appraising form and materials are placed in wrong bags, which all will bring certain trouble for graduates, and directly influence employment units' comprehensive understandings and evaluations to one person.

\subsection{Students' consciousness of archives is weak}

The workload of students' archives treatment at the eve of graduate is huge, and some colleges would arrange students to assist the work, and because of students' weak consciousness and knowledge of archives, some of them would modify the information, leak the content of archives, and take out the punishment materials in private. When the archives are required to be filled by the pen, some students would fill the archives by the ball pens, and when the archives are required to seal the cachet of the college, some students would seal the cachet of the department.

\subsection{The archives transmitting is complex}

According to the Archives Law and relative regulations, students' archives should be transferred by the secrete traffic or special personnel, and the transferring stage is very complex, some students' archives may be lost. In addition, many students would directly work in the society after graduate, and many of them need not archives, or the employment units are indifferent to these archives, and the personal department at the graduated students' registered residence has not the right and responsibility to keep graduates' archives, and the persons and their archives will be separated, and once the archives are lost, they are hard to be found again.

\section{Measures to perfect the college students' archives management work}

\subsection{Perfecting the archives management system and standardizing various management systems}

The archives work is divided into many parts including the collection, the treatment, the filing, and the keeping, and each part needs corresponding professional personnel to manage and guide, and corresponding systems need to be standardized, and the archives management system should be perfected, and the works should be brought into relative responsibility range, and to execute the management system effectively is the premise to manage students' archives well. Management personnel should properly guide the works of various filling departments according to the rules and characteristics of the archives work, and collect the archives from various departments in time. The archives materials which could not achieve the requirements should be withdrew firmly, and the filing task should be accomplished according to the quality requirements in time. To standardize various management systems is the essential guarantee to do college students' archives work well. First, the strict file registration and transfer system should be established. Second, management personnel should seriously register, treat, and check fresh students' archives at the beginning, and the words materials and sheets should be standardized to guarantee the integrity of the archives. Third, the archives transfer should follow strict transfer procedures, and each piece of graduate archives could be checked, and the management and check system about students' archives should be constituted.

\subsection{Strengthening the group construction of the students' archives management personnel}

Various colleges should implement the Regulations of General Universities and College Archives Management, pay more attention to the work of students' archives management, and carry out the organization institution and personnel allocation of the archives management, and enhance the management personnel's quality. First, the management personnel's work environment and condition should be improved positively, and corresponding equipments and capitals should be allocated properly, and good encouragement mechanism should be established. Second, professional and part-time management personnel should be trained for systematic archives theory and operation ability, and they also should study and manage corresponding scientific and cultural knowledge and basic theoretical knowledge about students' archives, and the colleges should provide opportunities for learning and communication, and these personnel's service ability and level should be enhanced, and the efficiency of the students' archives management should be continually enhanced. Third, the professional and part-time personnel's treatment should be enhanced, and some professional personnel with old age and abundant student archives management experiences should be supported in the titles and treatment, and the professional technical occupation appointive employment or the employee promotion system could be attempted. 


\subsection{Enriching and perfecting the content of students' archives}

The student archives could comprehensively reflect the result of the college quality education, and the employment units could also comprehensively know students' materials, so the content of students' archives should be added based on good registration archives management. First, students' archives should be treated according to different periods, and from the beginning of the enrollment, the archives taking the term as the unit should be collected with the content list, and students' archives should be standardized as more as possible, which could make students' archives to be transformed easily from the student archives to the personnel archives. Second, the filing range should be extended, and according to college students' learning and life trace, college students' psychological testing achievements, CET-4 and CET-6 certificates, computer level certificates, college students' ability and skill competition certificates, and social practice materials should be added in their archives. Third, the fresh students' enrollment education course, the selected course of archives management and the graduate employment guidance course, should be utilized to publicize the importance of the archives, and students should fully know the importance of the archives in the political examination, the confirmation, the title application, and the graduate enrollment, and students' archives consciousness should be strengthened, and students should consciously collect and inquire their own archives.

\subsection{Standardizing the archives transferring approaches and guaranteeing the transmitting security of archives materials}

The transferring work load of students' archives is large, and the time is urgent, and the participation personnel is numerous, and the consultation system and the transfer procedures should be strictly standardized to prevent the loss of archives. On the one hand, the colleges (departments) and the archives departments must educate students to establish strict secrecy concept and maintain the authenticity and the integrity of archives when they arrange students to participate in the archives work, and these students could not copy and take a picture of the archives, and they could not make postils, question marks, lineation, and clippings on the archives. On the other hand, the management personnel of students' archives should orient students, emphasize the concept of the people archives, and start from the minimum places, and carefully check graduates' graduate orientations, and transfer them to the employment units or local organizational and personal departments, and standardize strict handing-over procedures. The archives transferring management software of archives should be developed, so the archives transferring data could be input into the management system to enhance the efficiency of the inquiry.

\subsection{Establishing the electronic archives and enhancing the efficiency of students' archives management}

With the transformation from the higher education to the public education, the college enrollment expansion could induce the quick increase of the student amount, which brings large difficulty to the student archives management work, and the handle and paper operation management mode has not adopt the quick development of the modern higher education, and as the profitable complementation of the paper archives, the electronic archives will be the tendency of the archives development in the future. First, the modern information management technology archives should be enhanced, and many modern information management talents should be cultivated. At the same time, these talents should possess the basic theory and skill of archives management, the policy regulations, and operation standards of archives management, to realize the networking and digitalization of the archives management. Second, the new technology and equipment of the network should be fully utilized to establish the students' records, practice, technical innovation, psychological healthy, and poor students' electronic archives information system, and the texts, pictures, videos, and arts works in the archives should be digitalized, and the paper archives could be coexist with the electronic archives, and the modern management archives mode taking the automatic searching as the main using mode should be used to classify, storage, and transfer students' archives in detail, in order to realize the modernization of the archives management, which could not save many human resources, but easily realize the searching and inquiry of archives, and enhance the utilization rate of archives. Third, the networking of students' archives management should be pushed positively to realize the computer networking and share the information resources of students' archives. Most college networks have been established and used, which provide the utilization rate of the management networking of students' archives, and the informationization management of students' archives is an organic system, and various vertical and horizontal nodes of the system should all achieve certain level, and the completed automatic searching and inquiry system should be established in the network to exert the total advantages and realize the sharing of information resources. 


\section{References}

Chen, Wanbai \& Zhang, Yaocan. (2007). Principle of the Ideological and Political Education Theory. Beijing: Higher Education Press.

Feng, Yu. (2009). Collection of College Students’ Archives. Management Observer, No. 4, P. 210.

Liu, Xinrong, Yang, Li, Zhao, Baozhong \& Ai, Li. (2005). Problems of Students' Archive Management and Solutions. Journal of Southwest Jiaotong University (Social Sciences), No. 5, P. 131-133.

Wang, Qingyun et al. (2002). Modern Theory of Archives Management. Qingdao: Qingdao Press.

Yang, Li. (2008). On the Filling of College Students' Dossier. Yunnan Archives, No. 1, P. 39-40. 